\title{
A Management Innovation Approach to Project Planning
}

\author{
Haven Allahar
}

\author{
" Potential management innovators face severe barriers. For") \\ the most part they have not been trained to experiment \\ with processes, practices and structures, because that is not \\ what business schools do. Their companies do not have \\ organizational structures or incentive systems in place to \\ support management innovation.
}

Michael Mol and Julian Birkinshaw (2006)

Professors, researchers, and authors

\begin{abstract}
Innovation is viewed as indispensable to the economic and social development of countries, and the subject has been widely researched. The initial research focused on the development of new products and services by firms applying technological initiatives. The concept has expanded to cover many domains and features of innovation that led to innovation in non-technological areas, currently referred to as "management innovation". Many tools were developed by management specialists and gurus such as strategic planning, vision and mission statements, benchmarking, customer-satisfaction measurement, and outsourcing to target performance improvements in firms. The output of this article is a project development planning model that integrates management innovation tools related to the field of project planning as a novel approach tested by a consulting firm over several applications. The article has implications for managers, consultants, and professionals involved in the design, planning, and implementation of a varied range of development projects.
\end{abstract}

\section{Introduction}

The study of the theory and practice of innovation continues to generate considerable research articles and projects from academic and practical perspectives. The field has been broadened to include an array of innovation-related topics such as innovation management, open innovation triggered by the Internet, innovation in services as opposed to the traditional product focus, technology innovation, and management innovation as a more recent focus on non-technological innovation involving the employment of different organizational development tools by managers (Birkinshaw et al., 2008; Černe et al., 2015). While the focus on technological innovation remains critical to the sustainability and performance of leading firms, there is increasing attention being paid to the development and implementation of non-technological innovation initiatives (Meuer, 2014). This article focuses on management innovation, also referred to as organizational, administrative, and managerial innovation (Damanpour, 2014), and particularly the cutting-edge tools implemented by organizational managers over the past three decades. The key perspectives obtained from the literature and past and current management practice are described, and the most relevant management innovation tools are reviewed for an understanding of those tools that are applicable to the context of a small project development consulting firm. The question addressed is: "Which management innovation tools can be combined by a consulting firm for delivering project planning services?"

Research on innovation is a relatively recent area of investigation, which took off with the work of Drucker (1985) who argued that business innovation is based on a systematic analysis of the sources of opportunities, not flashes of inspiration. The early studies of innovation focused on the development of new products and new technologies, hence the definition of innovation as "the 


\section{A Management Innovation Approach to Project Planning}

\section{Haven Allahar}

embodiment, combination, or synthesis of knowledge in original, relevant, valued new products, processes, or services" (Harvard Business Essentials, 2003). Thus, innovation was initially viewed in purely technological terms and considered synonymous with invention. However, as the concept became the subject of studies, it was recognized that innovation could take several forms. Tidd, Bessant, and Pavitt (2005) identified four types of innovation: product innovation (referring to the actual offerings of firms); process innovation (involving the way in which products are created); position innovation (alluding to the context in which products are introduced); and paradigm innovation (involving changes in mental models of an organization). More recently, consideration of innovation in services, business models, pricing plans, market access, and management practices has emerged (Birkinshaw et al., 2011). In this context, two related managerial practices became of interest to researchers and practitioners grappling with how innovative projects in organizations could be effectively handled: the practice of innovation management and management innovation, which are often used interchangeably.

The concepts of innovation management and management innovation are related but differ in their application. For the purpose of greater clarity, innovation management observes a distinct process that begins with idea formulation and ends with implementation and incorporates network interrelationships among participants (Tanev et al., 2009). Further, innovation management is $R \& D$ oriented and is seen as the governance and organization of invention and innovation processes that evolved over periods of incorporating corporate $R \& D$ laboratories, then applying project management methods to R\&D, establishing functional internal collaboration within firms, and finally incorporating the knowledge of users and competitors to enhance the conduct of the R\&D function (Ortt et al., 2008). Management innovation, on the other hand, refers to the employment of new management practices, processes, initiatives, and structures with the aim of achieving organizational goals and objectives (Birkinshaw \& Mol, 2006). A major distinction is that management innovation is considered as non-technological innovation such as innovation in services, business models, and design and is generally considered an under-researched or generally overlooked area by scholars, particularly in the context of small and medium-sized enterprises (SMEs) (Aromaa \& Eriksson, 2014; Hervas-Oliver et al., 2016). It was suggested that "Management innovation is in many ways the missing piece of the innovation puzzle... needed to make technological innovation work yet it remains poorly understood and scarcely researched" (Mol \& Birkinshaw, 2006). Further, the existing research on management innovation was viewed as deficient as evidenced by: relatively few publications from an examination of published articles in leading journals (Damanpour, 2014); a mere $3 \%$ of articles addressing management innovation from an assessment of articles dealing with innovation (Crossan \& Apaydin, 2010); a limited understanding of the subject as a result of the preoccupation with the technological imperative (Meuer, 2014); and under-representation in the significant body of work on innovation (Volberda et al., 2014).

The aim of this article is twofold: 1) to provide an overview of the area of management innovation with a concise description of the key management practices for greater understanding by organization managers and the signficant audience listed below; and 2) to identify and explore the key management innovations that can be incorporated into a project planning methodology to answer the question posed in the article. This article contributes to filling research gaps by introducing a management innovation approach to project planning by applying a combination of select management tools and foresight planning as an emerging management tool to the practice of strategic project development planning as a novel and valuable contribution in the context of a small developing country. The results derived from the article are significant for organizational managers, in both the public and private sectors, who are pursuing new management innovation initiatives; firms seeking to gain a competitive edge in the market, especially those based in developing countries; researchers concerned with the subject of innovation in its many forms; and students interested in the study of entrepreneurship and innovation.

The research approach utilized a phased, sequential exploratory strategy comprising secondary research of relevant literature and an empirical analysis of the application of a combination of project planning related management innovations designed and tested by a project development planning consulting firm. The secondary data were sourced from: the leading digital full-text aggregator databases ABI/Inform ProQuest and EBSCOhost; Google Scholar; and reputable texts and reports related to the subject matter accessed from libraries and the Internet. The data were downloaded, sorted, and read, whereupon a thematic analysis was undertaken to identify patterns across the research data and identify the critical themes and issues through a process of data familiarization, coding, and theme development (Braun \& Clarke, 2006). 


\section{A Management Innovation Approach to Project Planning}

\section{Haven Allahar}

The results of the analysis were an achievement of a deeper understanding of the dynamics of the phenomenon of management innovation tools. Further, qualitative particularity, rather than generalizability, was achieved through the descriptions and themes developed for the particular research setting (Creswell, 2009; Saunders et al., 2009). The final phase involved an identification of the management innovations relevant to project planning, analysis of the merits of the project-related management innovations, and selection and incorporation of the select management innovations into the project development model. The theoretical underpinning of the article is based on the assumption that individuals introduce innovative solutions to organizational problems and follow up by championing the implementation and adoption of the solution (Birkinshaw et al., 2008) and by utilizing a rational perspective viewed as the dominant approach within a fragmented context (Damanpour, 2014).

The article continues with a discussion of the management innovation process, tools, and practices, highlighting the connectivity of the tools selected for the application to project development planning; a presentation of an integrated management innovation model as a novel application of a live example that captures management innovation in action; and the main conclusions generated from the discussion in the article and the pertinent managerial implications.

\section{Management Innovation Process, Tools, and Practices in a VUCA World}

The management innovation process was distinguished from technological processes by the greater use of external agents such as academics, consultants, and management gurus; by the creation of a highly interactive environment in which ex-employees can participate; and by the typical longer periods and diffuse nature of management innovations, which make it difficult to pinpoint when the innovations occurred (Birkinshaw \& Mol, 2006). Management innovations were also different as a result of the inability to gain patent protection; difficulty in observing and defining the process leading to greater subjectivity; lack of expertise and management capability in the area; and the addition of greater uncertainty and ambiguity from introducing new initiatives (Birkinshaw et al., 2008). For the benefit of management innovators, it was suggested that external management thinkers could provide inspiration to explore solutions to a current problem, an impending crisis, or a future threat; an internal champion can pursue internal and external validation and drive the process; and external validation can be supplied by business school academics, a reputable consulting company, media organizations, and industry associations (Birkinshaw \& Mol, 2006). However, the weakness of the management innovation process was the downplaying of the critical role of context relating to most management innovations, and examples from studies are deficient in explaining how context influences management innovation behaviour (Frynas et al., 2018).

An exploration of management innovation tools and practices revealed a wide range of initiatives introduced over a relatively short period, which illustrated a scattered picture of management innovation typologies and lack of an agreed classification (Damanpour, 2014). To demonstrate this situation, no agreed list of effective management innovations exists, but rather attempts at compiling lists were undertaken which identified: strategic planning, benchmarking, mission and vision statements, customer satisfaction measurement, and outsourcing as the main management innovations (Rigby, 2001); the top 10 management innovation tools that emphasized strategic planning, corporate social responsibility, benchmarking, mission and vision statements, outsourcing, knowledge management, and scenario planning as the leading management innovation tools (Dabić et al., 2013); and shortlisting 23 management innovations from a comprehensive list of 181 that was filtered based on completeness and popularity and with a detailed implementation process (Mol \& Birkinshaw, 2014). In an effort to rationalize and systematize the classification of management innovations, a categorization system was created comprising: efficiency-driven (e.g., service design, decentralized decision-making, continuous improvement, and participatory strategy development); externally recommended (e.g., decentralized logistic hubs, franchise systems, and activity-based costing); problem-oriented (e.g., involving debt management, user-oriented design, and collaborative supplier innovation); and opportunity-oriented (e.g., value-based selling, and business model thinking (Gebauer et al., 2017).

The literature on innovation is clear in pointing out that organizations utilize different innovation methods and strategies depending on their specific organizational characteristics and the environmental context in which they operate (Rothaermel \& Hess, 2010). A feature of the environment is that it is characterized by increasing volatility, uncertainty, complexity, and ambiguity (VUCA), a term introduced by the United States military at the end of the cold war in the late 


\section{A Management Innovation Approach to Project Planning}

\section{Haven Allahar}

1990s (Frynas et al., 2018). Volatility was created by economic factors such as currency fluctuations, which led to an unstable and unpredictable world environment; uncertainty derived from technological impacts on organizations and international trade; foreign direct investments in developed and developing countries introduced increased complexity in international finance; and ambiguity was created in situations where countries were faced with the choice of using local management practices versus adopting western theories (Frynas et al., 2018).

It was argued that a high VUCA environment in a developing-country context can stimulate novel management practices (Frynas et al., 2018), and this led to the formulation of VUCA-driven management innovation clusters including strategic leadership and management, business model innovation, innovation processes, organizational innovation, ecosystems, and strategic foresight (Millar et al., 2018). Successful management innovation in a VUCA world demands the development of dynamic capabilities that are based on early sensing of market changes, detecting shifts in behaviour, and gaining a deeper understanding of the implications for governmental regulations, technological advances, economic and sociopolitical trends, and seizing opportunities early and implementing innovative new systems (Schoemaker et al., 2018).

From the discussion to this point, it is clear that the field of management innovation is still in flux with new practices introduced as elements of management innovation that are exacerbated by the VUCA business environment. The impact is that management innovators are weary of creating new innovations in what has become a complex area of operation with a surplus of management tools, which overlap significantly. The interested manager will have to distil the information available on management innovation, assess the potential impacts on the organization, and evaluate the expertise for pursuing management innovation because, according to Birkinshaw and co-authors (2008), most companies do not have developed capacity in the area that increases uncertainty and ambiguity. Against this background, this article focuses on the management innovations that are directly aligned to the field of project development planning that are demonstrated to be successful innovations and include: business model innovation; open innovation; project management; design thinking; and foresight thinking and scenario planning, which were integrated into a novel project planning methodology as the main output of this article.

\section{Business model innovation}

A business model describes how a firm creates and delivers value and how innovating the model can create competitive advantage provided the innovation sufficiently differentiates the model (Teece, 2010). However, the author suggested that, in order to design and create a new model, "creativity, insight, and a good deal of customer, competitor and supplier information and intelligence" are required, implying high-level collaboration among stakeholders (Teece, 2010). Business models have experienced growth in practitioner-oriented studies and, while there is no agreement on what constitutes a business model, there is growing consensus that a business model is a new unit of analysis, operates on a system-level, and utilizes a holistic approach to firm operations with the aim of achieving value creation and capture (Zott et al., 2011). More succinctly, a business model is an "activity system", and "business model innovation is important to managers, entrepreneurs, and academics" who can achieve management innovations by adding novel activities which are linked in creative ways, and by changing members in the innovation team (Amit \& Zott, 2012). Business model innovation was linked to open innovation by authors who argued that "open innovation requires the adoption of new, open business models... which may prompt additional business model innovation" (Zott et al., 2011). However, the record of attempts at business model innovation revealed many failures that were attributed to the actual type of innovation attempted rather than the management innovators, from which it was suggested that, for greater success, managers should create new models rather than tinker with existing models (Christensen et al., 2016).

\section{Open innovation}

Chesbrough (2003) identified the difference between the traditional approach of closed innovation based on internally generated ideas and open innovation, which commercializes both internal and external ideas. The concept was initially restricted to the manufacturing sector but subsequently was expanded to incorporate services innovation based on co-creation with customers (Chesbrough, 2011), applied to the publishing industry as disruptive innovation (Allahar, 2017), predicted to extend to the design of new business models (Chesbrough, 2017), and eventually becoming "fully integrated in innovation management practices" (Huizingh, 2011), an example of which is the concept of living labs (Westerlund \& Leminen, 2011). 


\section{A Management Innovation Approach to Project Planning}

\section{Haven Allahar}

\section{Project-based management}

The concept of the project cycle emerged almost 50 years ago and became widely adopted, especially by development organizations such as the World Bank, because the techniques were well structured and had an internal logic (Landoni \& Corti, 2011). The practice of project-based management evolved from tools such as life-cycle project management, management of international development projects, and project knowledge management, which developed from the project management body of knowledge (Gasik, 2011; Jaafari, 2000; Khang, \& Moe, 2008; Tereso et al., 2018). According to Martinsuo and co-authors (2006), project-based management can be considered a management innovation with distinct features such as: a special focus on achieving scope, cost, time, and customer and business goals; introduction of a temporary structure to replace the existing organization structure; organization-specific tools and best practices; and improved distribution of project responsibilities within the organization. However, it was noted that project management was broadening its focus from an engineering-centric position to a strategic business perspective in sync with the impact of design thinking in the development of innovation.

\section{Design thinking}

The concept of design thinking emerged in the 1960s from the discipline of the design sciences, and the concept gained popularity within the management discipline. The concept was viewed as critical to the practice of management and management innovation, which led to the formulation of an experiential learning framework linked to design thinking tools and cultures (Elsbach \& Stigliani, 2018). The assertion made was that design thinking tools provide effective solutions to illdefined problems, which "starts the experiential learning cycle" that will "affirm and elaborate values, norms, and design thinking cultures" (Elsbach \& Stigliani, 2018). A selection of these tools include ethnographic interviews, brainstorming, customer co-creation, design drawings, design spaces, experimentations, acceptability of failure, and rapid prototyping. Design thinking began attracting the attention of researchers early in the 2000s and shares features with project management as both followed specific methods, applied tools in their processes, and were moving towards a strategic approach. A contention was that design projects followed a system of inspiration, ideation, and implementation and apply diverse approaches involving "observation, collaboration, fast learning, visualization of ideas, rapid concept prototyping, and concurrent business analysis" (Mahmoud-Jouini et al., 2016).
Design thinking employs a cognitive perspective, which alludes to its creative and explorative nature to meet the challenges of the VUCA environment; an organizational perspective, which emphasizes stakeholder involvement in the process and promotes new methodologies and tools such as living labs; and a strategic perspective, which highlights the adoption of strategic management capabilities that facilitate the spread of design practices throughout the organization (Mahmoud-Jouini et al., 2016).

\section{Foresight and scenario planning}

According to Greenblott and co-authors (2018), "strategic foresight is a method for systematically considering a longer time horizon and broader scope of issues than other forms of planning". These authors also suggest that strategic foresight methods, which include environmental scanning for gathering information on emerging or potential developments, trend analysis, and scenario planning that helps with addressing uncertainty, rapid change, and clarifying priorities, should be integrated into the planning system, because it "facilitates a systems approach to problem solving" which helps to "prepare for future threats or take early advantage of emerging opportunities" (Greenblott et al., 2018).

The tool was mainly utilized by the United States military and is not well respected in academia perhaps because it encourages challenging assumptions of the future, which makes persons tied to the status quo uneasy (Greenblott et al., 2018), and further it has not attained acceptance as a formal professional discipline (Hines et al., 2017). Foresight planning is integrally linked to scenario planning that follows a four-step procedure: first, a major environmental scan is conducted, which is maintained through the project development cycle but with less intensity; next, the results from the scan are used to develop a range of scenarios that consider possible futures; the third step utilizes workshops on the different scenarios to assess the implications for the project or the organization executing the project; and the last step involves the identification of the organizational capabilities required to successfully deal with the potential future events gleaned from the scenario analyses (Greenblott et al., 2018). Apart from military applications, foresight methods were applied to industrial development projects (Nehme et al., 2009), but are rare in the area of project development planning.

The discussion of the five management innovations highlighted in this article established close connectivity 


\section{A Management Innovation Approach to Project Planning}

\section{Haven Allahar}

among the concepts and practices, and generated guidelines for managers who pursue management innovation.

1. Managers must promote creativity, insight, and collaboration with customers, competitors, and suppliers to secure up-to-date business intelligence because business model innovation is challenging technological innovation as a major source of competitive advantage (Rayna \& Striukova, 2016), and a manager's task is to purposefully design and structure the business model (Amit \& Zott, 2012).

2. Failure in business model innovation is likely to continue especially in an environment of business ecosystem change in a context of sustainable circular business model innovation (Antikainen \& Valkokari, 2016). The lesson is that, for greater success, managers should create new models rather than tinker with existing models (Christensen et al., 2016).

3. Open innovation, facilitated by the Internet, has spawned a growing open access movement, which is impacting many areas of business and technology, and considered a useful lens for studying management innovation (Mol \& Birkinshaw, 2014).

4. The practice of project management consulting, which is critical to construction project delivery, requires a rethinking of consulting methodologies to develop more robust project management consulting approaches (Adesi et al., 2015).

5. Design thinking will introduce challenges, and such thinking should be embedded in the culture of organizations to deal with the challenges and the tensions between analytical and intuitive thinking and linear and lateral or iterative thinking (van Reine, 2017).

6. The integration of the management tools of strategic planning, foresight, and design thinking could improve "the adaptability and innovation capacity of organizations" (Bühring \& Liedtka, 2018). The lesson is that managers must be involved throughout the foresight process, noting that success results only after the long-term (Greenblott et al., 2018). Managers should also explore applying foresight methods to areas of consulting and organizational issues (Hines et al., 2017).

\section{A Project Planning Approach as an Innovation in Management}

This article outlines a methodology for planning, designing, and implementing projects by applying an approach that integrates the management innovation practices of business model innovation, open innovation, projectbased management, design thinking, and foresight and scenario planning (Greenblott et al., 2018; MahmoudJouini et al., 2016; Martinsuo et al., 2006). The model comprises a four-stage process of: 1) project framing, including project scoping and foresight approach; 2) research and environmental scanning for data collection and analysis; 3) foresight planning involving envisioning the alternative futures (Bishop et al. 2007; Hines et al, 2017); and 4) development of the implementation plan including identifying strategies, organizational resources, preparing operating guidelines, and conducting stakeholder consultations. The methodology identifies the tools to be used including brainstorming, focus group and project meetings, design thinking, and project management. The competencies needed include foresighting, environmental scanning, research analyses, futures search techniques, and scenario planning; and the major outputs are a project brief with fully developed scope of work, a database of research results, an agreed preferred future, and an implementation plan that integrates the key planning tools (Table 1).

The approach is the result of a distillation of the literature on management innovation and the management innovation tools and practices highlighted above. It also draws on empirical insights obtained by the author from an educational background in the discipline of project planning, years of management experience, project consulting practice, and as a future studies practitioner involved in the World Future Society (worldfuture.org), and AAI Foresight (aaiforesight.com). The method presented benefitted from an exercise in innovating the consulting value chain of the author's firm (Allahar, 2019) and empirical applications by the firm in completing specific development planning projects in areas of business parks, industrial estates, tourism, land development, new highways, and regional development.

The application of this method to the consulting sector contributes to addressing the gap in the existing literature on consulting practice assessed as "devoid of project management consulting methodologies" (Adesi et al., 2015). The strength of foresight as a management innovation is that it challenges assumptions about the future and helps managers question the status quo, although 


\section{A Management Innovation Approach to Project Planning}

\section{Haven Allahar}

Table 1. Integrated project planning methodology

\begin{tabular}{|c|c|c|c|c|}
\hline Stages & Framing $\rightarrow$ & Research/Scanning $\rightarrow$ & Foresight Planning $\rightarrow$ & Implementation \\
\hline Activities & $\begin{array}{l}\text { Project scoping, } \\
\text { foresight planning, } \\
\text { work planning, } \\
\text { finalizing the work } \\
\text { scope, conducting, } \\
\text { and negotiating with } \\
\text { clients and } \\
\text { participants }\end{array}$ & $\begin{array}{l}\text { Primary and secondary } \\
\text { data collection, sorting, } \\
\text { coding, and analysis } \\
\text { Scanning the } \\
\text { environment, situation } \\
\text { analysis }\end{array}$ & $\begin{array}{l}\text { Envisioning future } \\
\text { perspectives, identifying } \\
\text { alternative futures, } \\
\text { choosing the preferred } \\
\text { future, envisioning the } \\
\text { best outcomes, detailing } \\
\text { action goals, } \\
\text { performance measures }\end{array}$ & $\begin{array}{l}\text { Project implementation } \\
\text { strategies, organizational } \\
\text { guidelines, stakeholder } \\
\text { consultations, project plan and } \\
\text { recommendations }\end{array}$ \\
\hline Tools & $\begin{array}{l}\text { Project meetings, } \\
\text { brainstorming, focus } \\
\text { group interviews }\end{array}$ & $\begin{array}{l}\text { Literature reviews, } \\
\text { online and field surveys, } \\
\text { individual and group } \\
\text { interviews }\end{array}$ & $\begin{array}{l}\text { Strategic design thinking } \\
\text { and foresight workshops, } \\
\text { scenario analyses, and } \\
\text { organization analyses }\end{array}$ & $\begin{array}{l}\text { Project design, planning, and } \\
\text { management }\end{array}$ \\
\hline Skills & $\begin{array}{l}\text { Domain mapping, } \\
\text { organizational } \\
\text { foresight audit, } \\
\text { contract negotiations }\end{array}$ & $\begin{array}{l}\text { Research skills, survey } \\
\text { techniques, } \\
\text { environmental scanning; } \\
\text { content, stakeholder, } \\
\text { trend analyses }\end{array}$ & $\begin{array}{l}\text { Appreciative enquiry, } \\
\text { futures search, } \\
\text { visualization, scenario } \\
\text { planning, alternative } \\
\text { futures analysis, systems } \\
\text { analysis, technology } \\
\text { forecasting }\end{array}$ & $\begin{array}{l}\text { Decision modelling, simulations, } \\
\text { strategic planning, technology } \\
\text { assessment, activity scheduling, } \\
\text { design and management skills }\end{array}$ \\
\hline Output & $\begin{array}{l}\text { Confirmed project } \\
\text { brief, institutional } \\
\text { arrangements, } \\
\text { reporting system }\end{array}$ & $\begin{array}{l}\text { Information database } \\
\text { providing full } \\
\text { understanding of the } \\
\text { environment and the } \\
\text { boundaries of the } \\
\text { exercise }\end{array}$ & $\begin{array}{l}\text { Preferred future and } \\
\text { scenario implications }\end{array}$ & $\begin{array}{l}\text { Implementation plan linking - } \\
\text { project strategies, tactical } \\
\text { measures, project management } \\
\text { actions, implementation } \\
\text { organization, operating } \\
\text { guidelines, performance measure } \\
\text { tools, progress monitoring } \\
\text { system, project close }\end{array}$ \\
\hline
\end{tabular}

"foresight as a discipline is not well-recognized in academia" (Greenblott et al., 2018). However, it is an emerging practice in Latin America and the Caribbean in areas of agriculture and food production, ICT, and climate change, especially the application of strategic foresight, which differs from other planning tools by considering plausible, possible, probable, and preferred futures equally (Global Centre for Public Service Excellence, 2014). Design, creative thinking, and foresight principles are growing closer and contributing to enhancing planning processes resulting in the suggestion that combining the tools of these and related planning disciplines can provide a powerful toolkit (Bühring \& Liedtka, 2018). The project planning method presented in this article represents a novel application of a planning approach, which integrates five key management innovation tools as a contribution to the planning toolkit by a consulting firm operating in a developing country context.

\section{Conclusions, Managerial Implications, and Lessons}

The main conclusion is that the concept of innovation has evolved beyond considerations of manufactured products, innovation in services, and technology-related areas to an embrace of innovation in management tools and practices. While tools such as benchmarking, six sigma, supply chain management, business reengineering, the balanced scorecard, and business model innovation will remain relevant to organizations, the complexity of the VUCA environment forces managers 


\section{A Management Innovation Approach to Project Planning}

\section{Haven Allahar}

to explore non-technological innovations to deal with the challenges in the business world and non-profit organizations where social innovation is demanded. Overall, the management innovation process is viewed as complex, which creates a need for establishing legitimacy, "the bringing together of disparate pieces of knowledge and experience" and the involvement of external actors and sources of knowledge in the process (Mol \& Birkinshaw, 2014).

An example of a management innovation, based on the integration of the modern management innovation tools of project-based management, design thinking, and foresight and scenario planning, is presented as a potential solution in the field of project planning. The planning methodology proposed incorporates tested tools such as environmental scanning, research techniques, and data analyses, with scenario analysis, design thinking, future foresight, and project management. The application of these tools requires technological input involving the use of computers for systems analysis, technology forecasting, decision modelling, simulations, and project activity scheduling and milestone charting but is management-centred.

The discussion on management innovations and the conclusions reached have implications and lessons for managers seeking to build sustainable, competitive companies. The role of top management is to encourage managers and staff to explore and test new management innovations such as the creation of management innovation systems, noting that experimentation is integral to success; thus there is the need to "build a capacity for low-risk experimentation" (Birkinshaw \& Mol, 2006). In developing-country situations, managers should apply an "extended process model of management innovation", and management innovations should be aligned to the institutional, technological, and competitive environmental context, as well as the organizational structure, leadership, and resource context (Frynas et al., 2018).

Specific guidelines were suggested for managers to accelerate the innovation process by developing dynamic capabilities through the integration of functions and processes, promoting a culture of questioning and solution finding, searching for successful examples from other environments, becoming a conscious management innovator, and practicing serial management innovation (Millar et al., 2018; Birkinshaw \& Mol, 2006). As a summary statement, it was asserted that: innovation should be treated as a way of organizational life; managers must develop new skills and tools for staff applications to support design, foresight, and systems thinking; foresight processes should be an integral part of strategy; new business models must be created at the unit level; best practices should be explored from global best practices; and leaders and managers have a special responsibility to shape the future of organizations by building effective entrepreneurship ecosystems and networks (Millar et al., 2018), while managers are urged to evaluate different models and embrace an ecosystem perspective (Baden-Fuller \& Haefliger, 2013).

\section{About the Author}

Haven Allahar has served for over 25 years as an Adjunct Lecturer in entrepreneurship and innovation, and a coach of MBA teams' capstone projects at the Arthur Lok Jack Global School of Business of the University of the West Indies, Trinidad and Tobago. Haven has a wide academic and specialized training background in Economics (BSc, Jamaica), Entrepreneurship and Management (MA and DBA, US), Industrial Project Planning, Financing, and Management (UK and Poland). Haven served for over 40 years in senior management and CEO positions in companies involved in project planning and management, SME development, and urban development. Haven, along with two partners, owned and operated for 15 years a consulting firm that provided project planning, design, and management services to a variety of clients in Trinidad and Tobago and the Caribbean. Haven's research interests are in broad areas of business and management, and his publications are available at Academia.edu or ResearchGate. 


\section{A Management Innovation Approach to Project Planning}

\section{Haven Allahar}

\section{References}

Adesi, M., Owusu-Manu, D., \& Badu, E. 2015. Rethinking Methodology in Project Management Consulting Context. International Journal of Construction Project Management, 7(2): 79-100.

Allahar, H. 2017. Academic Publishing, Internet Technology, and Disruptive Innovation. Technology Innovation Management Review, 7(11): 47-56. https://doi.org/10.22215/timreview/1120

Allahar, H. 2019. Innovation Management and Value Chain Design: Case of a Small Professional Services Firm. International Journal of Innovation, 7(2): 192-209.

Amit, R., \& Zott, C. 2012. Creating Value through Business Model Innovation. MIT Sloan Management Review, 53(3): 41-49.

Antikainen, M., \& Valkokari, K. 2016. A Framework for Sustainable Circular Business Model Innovation. Technology Innovation Management Review, 6(7): 5-12. https://doi.org/10.22215/timreview/1000

Aromaa, E., \& Eriksson, P. 2014. Management of Innovation in Small Service Companies. South Asian Journal of Business and Management Cases, 3(1): 31-40.

http://dx.doi.org/10.1177/2277977914525253

Baden-Fuller, C., \& Haefliger, S. 2013. Business Models and Technological Innovation. Long Range Planning, 46(6): 419-426. https://doi.org/10.1016/j.lrp.2013.08.023

Birkinshaw, J., Bouquet, C., \& Barsoux, J-L. 2011. The 5 Myths of Innovation. MIT Sloan Management Review, Winter: 43-50.

Birkinshaw, J., Hamel, G., \& Mol, M. J. 2008. Management Innovation. Academy of Management Review, 33(4): 825-845. https://doi.org/10.5465/amr.2008.34421969

Birkinshaw, J., \& Mol, M. J. 2006. How Management Innovation Happens. MIT Sloan Management Review, 47(4): 81-88.

Bishop, P., Hines, A., \& Collins, T. 2007. The Current State of Scenario Development: An Overview of Techniques. Foresight, 9(1): 5-25. http://dx.doi.org/10.1108/14636680710727516

Braun, V., \& Clarke, V. 2006. Using Thematic Analysis in Psychology. Qualitative Research in Psychology, 3(2): 77-101. http://dx.doi.org/10.1191/1478088706qp063oa

Bühring, J., \& Liedtka, J. 2018. Embracing Systematic Futures Thinking at the Intersection of Strategic Planning, Foresight and Design. Journal of Innovation Management, 6(3): 134-152.

Černe, M., Jaklič, M., \& Škerlavaj, M. 2015. Management Innovation Enters the Game: Re-considering the Link Between Technological Innovation and Financial Performance. Innovation: Management Policy and Practice, 17(4): 429-449.

http://dx.doi.org/10.1080/14479338.2015.1126530

Chesbrough, H. W. 2003. The Era of Open Innovation. MIT Sloan Management Review, Spring: 35-41.

Chesbrough, H. W. 2011. Bringing Open Innovation to Services. MIT Sloan Management Review, Winter: 85-90.

Chesbrough, H. W. 2017. The Future of Open Innovation. ResearchTechnology Management, 60(1): 35-39.

https://doi.org/10.1080/08956308.2017.1255054
Christensen, C. M., Bartman, T., \& van Bever, D. 2016. The Hard Truth about Business Model Innovation. MIT Sloan Management Review, 58(1): 31-40.

Creswell, J. W. 2009. Research Design: Qualitative, Quantitative, and Mixed Methods Approaches (3rd ed.). Thousand Oaks, CA: SAGE Publications.

Crossan M. M., \& Apaydin, M. 2010. A Multi-Dimensional Framework of Organizational Innovation: A Systematic Review of the Literature. Journal of Management Studies, 47(6): 1154-1191. http://dx.doi.org/10.1111/j.1467-6486.2009.00880.x

Dabić, M., Potocan, V., Nedelko, Z., \& Morgan, T. R. 2013. Exploring the Use of 25 Leading Business Practices in Transitioning Market Supply Chains. International Journal of Physical Distribution and Logistics Management, 43(10): 833-851. http://dx.doi.org/10.1108/IJPDLM-10-2012-0325

Damanpour, F. 2014. Footnotes to Research on Management Innovation. Organization Studies, 35(9): 1265-1285. https://doi.org/10.1177/0170840614539312

Drucker, P. 1985. Entrepreneurship and Innovation: Practice and Principles. New York, NY: HarperCollins.

Elsbach, K. D., \& Stigliani, I. 2018. Design Thinking and Organizational Culture: A Review and Framework for Future Research. Journal of Management, 44(6): 2274-2306. http://dx.doi.org/10.1177/0149206317744252

Frynas, J. G., Mol, M. J., \& Mellahi, K. 2018. Management Innovation Made in China: Haier's Rendanheyi. California Management Review, 61(1): 71-93. https://doi.org/10.1177/0008125618790244

Gasik, S. 2011. A Model of Project Management. Project Management Journal, 42(3): 23-44. http://dx.doi.org/10.1002/pmj.20239

Gebauer, H., Haldimann, M., \& Saul, C. J. 2017. A Typology for Management Innovations. European Journal of Innovation Management, 20(4): 514-533.

http://dx.doi.org/10.1108/EJIM-06-2016-0059

Global Centre for Public Service Excellence (GCPSE). 2014. Foresight as a Strategic Long-Term Planning Tool for Developing Countries. Singapore: GCPSE.

Greenblott, J. M., O'Farrell, T., Olson, R., \& Burchard, B. 2018. Strategic Foresight in the Federal Government: A Survey of Methods, Resources, and Institutional Arrangements. World Futures Review, Online first, December 13, 2018: 1-22. http://dx.doi.org/10.1177/1946756718814908

Hervas-Oliver, J.-L., Repoll-Sempere, F., \& Moll, C. B. 2016. Does Management Innovation Pay-Off in SMEs? The Empirical Evidence from Spanish SMEs. 2015. Small Business Economics, 47(2): 507-533.

http://dx.doi.org/10.1007/s11187-016-9733-x

Hines, A., Gary, J., Daheim, C., \& van der Laan, L. 2017. Building Foresight Capacity: Toward a Foresight Competency Model. World Futures Review, 9(3): 123-141.

https://doi.org/10.1177/1946756717715637

Harvard Business Essentials. 2003. Managing Creativity and Innovation: Practical Strategies to Encourage Creativity. Boston, MA: Harvard Business School Press. 


\section{A Management Innovation Approach to Project Planning}

\section{Haven Allahar}

Huizingh, E. K. R. E. 2011. Open Innovation: State of the Art and Future Perspective. Technovation, 31(1): 2-9.

https://doi.org/10.1016/j.technovation.2010.10.002

Khang D. B., \& Moe, T. L. 2008. Success Criteria and Factors for International Development Projects: A Life-Cycle-Based Framework. Project Management Journal, 39(1): 72-84. https://doi.org/10.1002/pmj.20034

Jaafari, A. 2000. Life-Cycle Project Management: A Proposed Theoretical Model for Development and Implementation of Capital Projects. Project Management Journal, 31(1): 44-52. https://doi.org/10.1177/875697280003100107

Landoni, P., \& Corti, B. 2011. The Management of International Development Projects: Moving Toward a Standard Approach or Differentiation? Project Management Journal, 42(3): 45-61. http://dx.doi.org/10.1002/pmj.20231

Mahmoud-Jouini, S. B., Midler, C., \& Siberzahn, P. 2016. Contributions of Design Thinking to Project Management in an Innovation Context. Project Management Journal, 47(2): 144-152. https://doi.org/10.1002/pmj.21577

Martinsuo, M., Hensman, N., Artto, K., Kujala, J., \& Jaafari, A. 2006. Project-Based Management as an Organizational Innovation: Drivers, Changes, and Benefits of Adopting Project-Based Management. Project Management Journal, 36(3): 87-97. https://doi.org/10.1177/875697280603700309

Meuer, J. 2014. Archetypes of Inter-Firm Relations in the Implementation of Management Innovations: A Set-Theoretical Study in China's Biopharmaceutical Industry. Organization Studies, 35(1): 121-145. http://dx.doi.org/10.1177/0170840613495339

Millar, C. C. J. M., Groth, O., \& Mahon, J. F. 2018. Management Innovation in a VUCA World. California Management Review, 61(1): 5-14.

http://dx.doi.org/10.1177/0008125618805111

Mol, M. J., \& Birkinshaw, J. 2006. Against the Flow: Reaping the Rewards of Management Innovation. European Business Forum, 27: $24-30$.

Mol, M. J., \& Birkinshaw, J. 2014. The Role of External Involvement in the Creation of Management Innovations. Organization Studies, 35(9): 1287-1312.

http://dx.doi.org/10.1177/0170840614539313

Nehme, C. C., Galvao, A., Vaz, A., Coehlo, G., \& Fellows, L. 2009. A Foresight Method for Enhancing Competitiveness of Brazilian Industrial Sectors. In C. G. Wagner (Ed.), Innovation and Creativity in a Complex World: 115-131. Chicago, IL: World Future Society.

Ortt, J. R., \& van der Duin, P. A. 2008. The Evolution of Innovation Management towards Contextual Innovation. European Journal of Innovation Management, 11(4): 522-538. http://dx.doi.org/10.1108/14601060810911147
Rayna, T., \& Striukova, L. 2016. $360^{\circ}$ Business Model Innovation: Toward an Integrated View of Business Model Innovation. Research-Technology Management, 59(3): 21-28. https://doi.org/10.1080/08956308.2016.1161401

Rigby, D. 2001. Management Tools and Techniques: A Survey. California Management Review, 43(2): 139-160. https://doi.org/10.2307/41166079

Rothaermel, F. T., \& Hess, A. M. 2010. Innovation Strategies Combined. MIT Sloan Management Review, 51(3): 13-15.

Saunders, M., Lewis, P., \& Thornhill, A. 2009. Research Methods for Business Students (5th ed.) Harlow, UK: Pearson Education.

Schoemaker, P. J. H., Heaton, S., \& Teece, D. 2018. Innovation, Dynamic Capabilities, and Leadership. California Management Review, 61(1): 43-70. http://dx.doi.org/10.1177/0008125618790246

Tanev, S., Knudsen, M. P., Bisgaard, T., \& Thornsen, M. S. 2011. Innovation Policy Development and the Emergence of New Innovation Paradigms. Technology Innovation Management Review, 1(2): 14-19.

https://doi.org/10.22215/timreview/496

Teece, D. J. 2010. Business Models, Business Strategy and Innovation. Long Range Planning, 43(2-3): 172-194. https://doi.org/10.1016/j.lrp.2009.07.003

Tereso, A., Ribeiro, P., Fernandes, G., Loureiro, I., \& Ferreira, M. 2018. Project Management Practices in Private Organizations. Project Management Journal, 50(1): 1-17. http://dx.doi.org/10.1177/8756972818810966

Tidd, J., Bessant, J., \& Pavitt, K. 2005. Managing Innovation: Integrating Technological, Market and Organizational Change (3rd ed.). Chichester, UK: John Wiley \& Sons.

van Reine, P. P. 2017. The Culture of Design Thinking for Innovation. Journal of Innovation Management, 5(2): 56-80. https://doi.org/10.24840/2183-0606_005.002_0006

Volberda, H. W., Van Den Bosch, F. A. J., \& Mihalache, O. R. 2014. Advancing Management Innovations: Synthesizing Processes, Levels of Analysis, and Change Agents. Organization Studies, 35(9): 1245-1264. http://dx.doi.org/10.1177/0170840614546155

Westerlund, M., \& Leminen, S. 2011. Managing the Challenges of Becoming an Open Innovation Company: Experiences from Living Labs. Technology Innovation Management Review, 1(1): 19-25. https://doi.org/10.22215/timreview/489

Zott, C., Amit, R., \& Massa, L. 2011. The Business Model: Recent Developments and Future Research. Journal of Management, 37(4): 1019-1042. http://dx.doi.org/10.1177/0149206311406265 


\section{Academic Affiliations and Funding Acknowledgements}
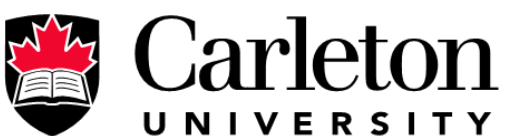

U N I V E R S I T Y

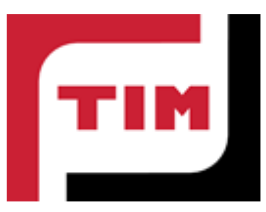

Technology Innovation Management (TIM; timprogram.ca) is an international master's level program at Carleton University in Ottawa, Canada. It leads to a Master of Applied Science (M.A.Sc.) degree, a Master of Engineering (M.Eng.) degree, or a Master of Entrepreneurship (M.Ent.) degree. The objective of this program is to train aspiring entrepreneurs on creating wealth at the early stages of company or opportunity lifecycles.

- The TIM Review is published in association with and receives partial funding from the TIM program. 